2018-01-19

\title{
Christopher Smart and the Cartographic Imagination
}

\author{
Wild, Min
}

http://hdl.handle.net/10026.1/10258

10.1093/res/hgx131

The Review of English Studies

Oxford University Press (OUP)

All content in PEARL is protected by copyright law. Author manuscripts are made available in accordance with publisher policies. Please cite only the published version using the details provided on the item record or document. In the absence of an open licence (e.g. Creative Commons), permissions for further reuse of content should be sought from the publisher or author. 


\section{Christopher Smart and the Cartographical Imagination}

\section{Min Wild}

University of Plymouth

This is the author's accepted manuscript. The final published version of this work (the version of record) is published by Oxford University Press in The Review of English Studies available at: DOI: 10.1093/res/hgx131. This work is made available online in accordance with the publisher's policies. Please refer to any applicable terms of use of the publisher.

This essay identifies within Smart's mid-century writings those places where he is seized by what D.K. Smith called the 'cartographical imagination'; new ways of delineating and describing terrestrial space find expression in his religious poetry. This topographical borrowing is not simply on the level of concept or imagination, however: I find several striking examples where he describes a specific map or cartouche, and reveal a 'mapminded' Smart who enjoyed and knew well the visual colour and life of Enlightenment cartography, but who was disquieted by some of its silent rhetorical arrogation of divine power. I turn later in the essay to his secular writings in the Midwife magazine, and identify how in 1750 Smart used a specific sixteenth-century anthropomorphic map (devised at the time to symbolise a united Christian Europe) as a vehicle for political satire and bad jokes. This satirical prose description of the map of Europe transformed into an 'Old Woman' is also a more explicit articulation of Smart's distrust of cartographic representation and its all-too-human concerns. Ultimately, amidst the banter and the play, Smart's idiosyncratic presentation demonstrates his early grasp of twenty-first century cultural geography's insight: that the claim of maps to transparent authenticity is a matter of deception. 
Attest, and praise, ye quarters of the world!

Bow down, ye elephants, submissive bow

To him, who made the mite; tho' Asia's pride,

Ye carry armies on your tow'r-crown'd backs,

And grace the turban'd tyrants, bow to him

Who is as great, as perfect and as good

In his less-striking wonders, till at length

The eye's at fault and seeks th'assisting glass.

(Christopher Smart, 'On the Goodness of the Supreme

Being', 1756: 11. 86- 93)

Christopher Smart made the poetic elephants in his 'On the Goodness of the Supreme Being' (1756), stand for Asia, although by cartographic convention, they should represent Africa. ${ }^{1}$ He had also ventured East in this prizewinning poem, when earlier - in a swift and concisely vivid depiction of self-conscious flowers reflected in a still stream - he demoted royalty in their favour. Were it not for the sun, the pansies that ' $[\mathrm{v}]$ iew ... [ $\mathrm{t}]$ heir portraiture in the inverted heaven' would lose

their triple boast, the white,

The purple, and the gold, that far outvie

The Eastern monarch's garb. ${ }^{2}$

In Smart's devotional verse - concerning so often questions of scale - we see a special form of Christian levelling: metonymically, the elephant must bow to the mite, for both know who made them; the powerful must give place to the little flowers in the sun's light. ${ }^{3}$

This most exuberant of eighteenth-century poets - trained in a Ciceronian rhetoric that 
calls for the lifelike, concise sketching of a scene - uses the visual in arresting modes not yet examined. ${ }^{4}$ This essay shows how Smart both valued and questioned cartographical convention, and demonstrates the creative ways that cartographical conventions allowed Smart to emphasise his commitment to an analogical, emblematic view of the world 'in which the spiritual finds its analogy in the physical creation': such a move being in itself representative of older, endangered orders of understanding. ${ }^{5}$ His rhetorical exuberances here recall Marvell's games with perspective, but, in this new order of understanding, questions of scale are also at the heart of mapmaking. Whilst in 'On the Goodness' 'the general chorus of all worlds' is summoned to praise God, its 'song of charity' shows the divinity stooping very low, and seeing very small: for God 'to lowliest minds [does] condescend'. ${ }^{6}$ Our eye may fail, and 'seek th'assisting glass', but his never will. God needs no intermediary, because he is the first cause and the cause of himself, but as fallen humans we always will. Smart showed boisterous resistance to the conceptual changes that Enlightenment modes and techniques of accurate measurement seemed to require of Christians. Is God's meticulousness as a maker now challenged by man's accuracy as a measurer and surveyor?

Smart's love of energetic concision, I will argue, leads him to turn sometimes in his writings to maps and their supplementary images, not only as imagined, remembered or envisaged, but as described: actual physical maps. They offer him an effective form of symbolic shorthand for conveying the cosmological and the terrestrial, but they also serve in his writing as provocative adversaries, their very confidence a way to help him register his disquiet about modern kinds of claim to authenticity. Whilst Smart was not inimical to Enlightenment models of scientific enquiry, he was also uncomfortable with mid eighteenthcentury confidence in Newton's findings in the study of light, optics and cosmology. ${ }^{7}$ This unease is evident in Smart the energetically witty, punning hack and also in Smart the devotional poet, for though their rhetorics operate in different registers, they are the same 
man. Karina Williamson sees in the poet a 'broad evolution from an academic and popular versifier to an ardent and dedicated Christian poet', and this works too for the ingenious shaper of comic prose, the self-proclaimed 'scribe-evangelist' who habitually employs the same conceptual leap as the poet: the shift from the individual to the group. ${ }^{8}$

Harriet Guest has noted 'the movement of [Smart's] poetry between general survey and particular detail' which 'expresses a landscape of animated analogy' and Clement Hawes observed in the Jubilate Agno (?1759-1763) his tendency to 'vault outward on a map of concentrically nested geographical scales', as a form of imaginative escape from his asylum confinement. ${ }^{9}$ Yet I suggest that a very similar leap into mapminded immensity was already there in the Seatonian poems, for all imprisonments are not physical. In the same year that Smart the hard-pressed hack was teasing mapmakers - see below - Smart the devotional poet was sharing with his readers his praise for 'the Architect of countless worlds', using ' $[\mathrm{t}] \mathrm{h}$ ' ambition of the comprehensive eye,/ That dares to call th' Horizon all her own': invoking the scopic immanence of God through the eyes of a cartographer. ${ }^{10}$ The conventions of mapmaking gave Smart a crisply condensed symbolic vocabulary for his global surveys. Yet he also demonstrated their limits, so that this essay shows not only how Smart deployed one significant aspect of Enlightenment thought, but also how he put it under question.

We turn now to Smart looking at - or remembering vividly - specific, physical maps. In 'On the Goodness' the emblematic quality of the descriptive vignettes of the four continents is plain - 'Africa' is exampled in my epigraph - but I suggest that he is not simply giving an imagined account of typical attributes (poor submissive Africa; the lions with their 'surly' coughing roar) but is thinking of specific cartouches on particular maps of his time. ${ }^{11}$ We know that Smart had consulted John Senex's New General Atlas, and the anomaly in my epigraph is explained when we see that in Senex's 1721 cartouche for Asia, an elephant's trunk cuts across the 'Eastern monarch's garb' on the right. ${ }^{12}$ Sometimes, in Smart, then, is a 
vivid poetic image a form of cartographical ekphrasis? Three times in this essay I discuss poetic images that are also visual images in Senex's Atlas. ${ }^{13}$

Hacks and maps often collided in print-hungry London: in 1756, the year of 'On the Goodness', Smart's name heads the list of authors at the start of John Newbery's massive twenty-volume World Displayed, or A Curious Collection of Voyages and Travels (1759). ${ }^{14}$ Colourful, figurative cartouches like the ones Senex used made early maps - beyond their crucial practical value - into culturally important documents, and also offered an easy, ready way to figure concisely the continents: Smart's descriptions in 'On the Goodness' evoke them strongly. ${ }^{15}$ Senex's General Atlas cartouches show the typical continental emblems: for Asia, Smart's 'turban'd tyrant', for his 'Araby the blest', a thurible to carry its 'fragrant cassia, frankincense and myrrh', and for Africa, the obligatory pyramids and lion. Smart's figuration ' - '[s]toop, sable Africa, with rev'rence stoop' - bears also a strong resemblance to the cartouche for Africa in J. B. Homann's 1720 Nuremberg atlas. ${ }^{16}$ In all cases, resemblances between word and maply image are striking.

Central here is D.K. Smith's view of how the new certainties of Euclidean geometry and the increasing sophistication of measuring techniques and instruments in the sixteenth century led, albeit unsteadily, to a new kind of faith: a faith in the verifiable certainties of mapmaking. People begin to believe that 'the objects in the world to be mapped are real and objective, and that they enjoy an existence independent of the cartographer. ${ }^{17}$ In the light of this, new conceptual models of representing information become available to writers, and thus - building on P.D.A. Harvey's description of 'mapmindedness' - attention to the 'cartographic imagination' in seventeenth-century texts can offer new insights into familiar texts. ${ }^{18}$ Smith's view that '[a] map's interpretive structures may be applied to imaginative, as well as physical relationships' applies in the eighteenth century too: not just for poetry or the emergent novel, but also for Christian readings of the world God made: cartographical 
imagining' is 'concerned not simply with the ways in which the world is spatially organized, but with the way those discourses of imagined space enable other ideas and concepts to be organized and treated.' 19

Confidence in the absolute truth offered by a map with all its sums right, then, could underwrite confidence in the visual and the abstract, in the diagram and the navigational chart, and this enabled new ways of conceptualising physical environments. But old habits of thinking did not go quietly, for the Enlightenment map retains other impulses. Its artistic, creative touches, the cartouches and moments of fantastical play on the surfaces of oceans become significant, as evidence of the way that history and culture are always present in maps, as Peter Barber has observed. ${ }^{20}$ A belief in maps as bearers of absolute truth, the new cultural geography now insists, is misplaced: since 1987 Brian Harley and David Woodward's definition of maps as cultural, perspectival objects has been accepted by 'most people working on the academic study of maps. ${ }^{, 21}$ To them, 'maps are graphic representations that facilitate a spatial understanding of things, concepts, conditions, processes, or even events in the human world. ${ }^{22}$

Michel de Certeau set up an opposition between these two kinds of informationgiving. The map, he argued, 'transformed by Euclidean geometry and then descriptive geometry', over time forces to the margins its own history, to be seen at last only in those playful touches, the mermaids and leviathans. These are not mere illustrations: they 'mark on the map the historical operations from which it resulted.' The little ships - 'the sailing ship painted on the sea indicates the maritime expedition that made it possible to represent the coastlines' - and the cherubs who make the winds are elbowed out by the demands of a different kind of epistemology. ${ }^{23}$ Yet the dialogue between old and new is reciprocal, for in some seventeenth-century maps, the cherubs are given telescopes and dividers and cross staffs: are made to brandish the very instruments of their own destruction. Senex's New 
General Atlas has cherubs with cross staffs on the 'Europe' map, and this cartouche also bears a strong resemblance to Smart's 'On the Goodness' characterisation of the continent. To Bernard Klein “just as the mathematical textbook claims access to absolute truth, cosmographer and surveyor profess a representational ... accuracy approaching divine perfection': this may have been so, but there were some who - given orthodox Christian doctrine - found this discomforting, and clearly signalled that fact. ${ }^{24}$

Abraham Ortelius, in the first atlas ever, the Theatrum Orbis Terrarum of 1570, made it clear whose territory was under threat when he gave his centrepiece this motto: 'What in human life can seem vast to the one who knows eternity and the expanse of the whole world? ${ }^{25}$ The business of 'experience and proof' enters in a merely supplementary, confirmatory role to that of 'belief and faith' in an early English version: Ortelius conjures the whole world as 'a mirror of most great admiration, wherein the unsearchable science of the all-surpassing Artisan is to be seen. ${ }^{26}$ The mapmaker John Speed has an elaborate, scriptural preface, giving God the credit for this 'widow's mite' - 'the Lord composed my mind for the work': that is, the labour of making his Theatre of the Empire of Great Britain (1611), a regional atlas that Klein called the 'summary of four decades of English cartographic activity. ${ }^{27}$ Despite their initial, brief fervency, these statements may look like lip service to convention, before the maps seize their full powers of naming, measuring and disposition.

Both the decorations and the prolegomena of early maps, then, can contradict the very claim to accuracy that they themselves make. As Barber says, maps are immensely 'successful fictions': 'most of their users instinctively suspend disbelief until the unpleasant reality is forced on them' and their military map, say, is inaccurate. ${ }^{28}$ Despite his beautiful illustration of the trap, this does not feel quite right, since maps are not stories as such. ${ }^{29}$ It seems to me that the trust they so beguilingly offer in their ultimate accuracy is not narrative, 
but something else: a very successful form of silent rhetoric. ${ }^{30}$ The fact that there is always an agenda to a map is almost a given nowadays, but what is perennially eloquent about a map is its claim not to have one - and the more apparently value-free and accurate the map, the more urgent the dumb persuasion: hence the drive to counterbalance, as with Ortelius's motto.

Who better to unmask the silent rhetorical force of the early modern map but the most rhetorically gifted periodical satirist of his day, the man who had already identified other forms of dumb rhetoric? ${ }^{31}$ And who better to question human claims to divine power than a man who was acknowledged as one of the most skilful devotional poets of his generation? Already we have seen Smart employing inventively his own 'mapmindedness' - writing in ways which suggest cartographical visualisation. We can also, though, observe his scepticism about the very possibility of an unconsidered faith in human calculations, when a stronger and deeper one already exists. If you have an eye for concealed agendas in verbal rhetoric you may more readily have insights into the tricks played by the visual kind. ${ }^{32}$ Smart was of course not the only one to see this, but he registered in uncommon and ingenious ways the fact that - to augment Harley's definition - 'maps are graphic representations that claim to facilitate a spatial understanding of things ... in the human world. ${ }^{, 33}$

Before the scepticism, however, must come the understanding - and sometimes the appreciation. In much of his verse, in the Psalms, the hymns for children and adults, and in the Seatonian poems, Smart writes in ways which suggest imaginative visualisation from a cartographer's perspective. He frequently adopts a global panoramic view, recalling Michel de Certeau's mapmaking 'solar Eye', working from a privileged viewpoint. ${ }^{34}$ The poet may sometimes share God's view in Smart's religious verse, but only in order to indicate his Maker's plenitude, eager to 'indulge/ Th' ambition of the comprehensive eye, / That dares to call th' Horizon all her own.' Heartfelt thanks encompass Smart's devotional end and beginning: '[a]s in a virtuous circle, the expression of gratitude seems to trigger in [him] yet 
more awareness of participating in a joyous universe. ${ }^{35}$ These panoramic surveys inevitably carry a cartographic charge as features of the natural world - mountains and oceans - are seen all at once over the flat plane of the atlas page. One example of this kind of spatialising consciousness is in Smart's version of Psalm 8, where in search of global gratitude the poet and the psalmist range together, through 'heav'n above, in earth and air,/ And in the vast profound!'36

Many of Smart's 1763 psalm translations draw out like this for the long view, even when their parent verse in the Book of Common Prayer's Psalter does not. ${ }^{37}$

Smart's Psalm 24 includes the cartographical in revealing ways:

The earth is God's, with all she bears

On fertile dale or woody hill;

The compass of the world declares

His all efficient skill.

For her foundations has he laid,

The flowing waters to restrain,

And all her firm consistence made

Upon the mighty main. [my emphases] $]^{38}$

Both the compass and the founding are there in the Book of Common Prayer's Psalter, and 'compass' can have in both the simple meaning of 'encompassing.' The Psalm verse is simply ' $[t]$ he earth is the Lord's, and all that therein is: the compass of the world, and they that dwell therein.' Here, though, the central instrument of Enlightenment mapmaking is hijacked, and turned away from measurement of the modern secular world. The compass is made human, its rhetoric redirected to describe its Creator's power. In the second stanza, we can note perhaps as present the new 'context of certainly and reliability' that the 
technological improvements in mapmaking brought - that 'firm consistence' - but undoubtedly in Smart's view all foundations are God's: the new technology simply confirms his permanence. The 1733 Psalter's second verse is laconic, and the senses of restraint and permanence present in Smart's translation, are absent: 'For he hath founded [the earth] upon the seas: and prepared it upon the floods. ${ }^{39}$

As early as 1750, in the first of his five Seatonian poems, 'On the Eternity of the Supreme Being', Smart seems to be anatomising divine mastery over mere human instruments. Smart's God is active, for though the worlds he makes are countless, each one is assured and validated:

No-in th'exertion of Thy righteous pow'r,

Ten thousand times more active than the Sun,

Thou reign'd, and with a mighty hand compos'd

Systems innumerable, matchless all,

All stampt with Thine uncounterfeited seal. ${ }^{40}$

The plumbline has no power to authenticate in these realms, that in his Easter Day hymn Smart characterises as '[b]eyond the heights that science kens'. ${ }^{41}$ In both Smart's lyrics and his prose, however, these ideas are not solely metaphysical. We can plainly see him registering on occasion the material map or atlas as a physical object. ${ }^{42}$

The visual impact of looking at directly at a map is registered in many more of Smart's devotional poems. Smart places whales in his oceans with what seems a decorative cartographer's care: as in his 'On the Immensity of the Supreme Being', where

$$
\text { ... Leviathan }
$$

The terror and the glory of the main 
His pastime takes with transport, proud to see

The ocean's vast dominion all his own. ${ }^{43}$

Smart specialised in cheerful whales for his Magnificats: in 'Song to David', 'Strong against tide, the enormous whale/ Emerges, as he goes' (11. 455-456), and in Psalm CIV, the sea is where 'that Leviathan resorts/ Which at thy blessed bidding sports/ At leisure and at large.'

In 'Song to David' (1763) he delineates another symbol common in a mapmaker's vocabulary, and his mermaid makes the cartographical impulse explicit, whilst her infant engenders a typically deft Smartian pun:

\section{All scenes of painting crowd the map \\ Of nature; to the mermaid's pap \\ The scalèd infant clings 44}

Yet this is also a visual prompt of a different nature: 'all scenes of painting' are not simply those on maps, and whilst marine mermaids on maps are uniformly depicted about their normal siren's business with mirrors, there is elsewhere a striking image of a breastfeeding mermaid: in the celebrated medieval Alphonso Psalter. Smart may have seen this in Kent as a small boy, and it is especially appropriate to his description. ${ }^{45}$ It is certainly a memorable, luminous image, in which a mermaid's girlchild (decorated strangely with a small pap of her own) clings not to the breast but the arms of her serene mother, who is squeezing her own breast between expressive finger and thumb.

The emblematic cherubs of the four winds invoked by de Certeau are present too in the 'Song to David', for, three stanzas later, an otherwise mysterious reference becomes transparent when placed at the apex of an atlas's title page. The winds abate when spring is growing into summer: 'Nor in the pink and mottled vault/ The opposing spirits tilt., ${ }^{46}$ It is seldom that our sky looks precisely 'pink and mottled'- this may only be dawn or sunset 
specific - but used to describe a paper page, colour stained and stippled, the words are crisply accurate. The title page of Matthew Seutter's Atlas Novus (1735) has exactly such stippling on the pink clouds through which the cherub winds contend. ${ }^{47}$

Smart is again cartographical with his John Martinesque apocalypse in the 'Eternity of the Supreme Being' (1750), for now, only 'glow-worms to the golden sun' are the mighty mountains

on whose cloud-crown'd tops the cedars

Are lessen'd into shrubs, magnific piles,

That prop the painted chambers of the heav'ns. ${ }^{48}$

This surely recalls the emblematic flattening of cartographic mountains and their trees into a planisphere, and for this there is a direct example. In Senex's New General Atlas, which we know Smart saw, the clearest representation of such a miniaturisation is on the slopes of Mount Etna, in the large-scale plate for Sicily. Three lines after this envisioning in the same poem, the poet is asking 'What, Aetna, are thy flames to these?" ${ }^{49}$ (This poem of the Last Days is returned to in a different context below.) Maps flatten three dimensions into one, and turn cedars, at once the tallest and most Biblical of trees available to the early modern imagination, into tiny gestures on paper, for it is only painted heavens that these shrunken symbolic trees can support. ${ }^{50}$ In her insistence on the centrality to Smart of the entire Bible as a unified document, Harriet Guest summons from the Jubilate Agno 'Otis' [the great bustard] who looks about him for the glory of God, \& sees the horizon compleat at once.' These lines - 'for the word of God is a sword on my side' - help Guest to illustrate Smart's 'view of the Bible as a synchronic "landscape" ': this is of course what maps are. ${ }^{51}$

The cherub winds also cease to blow, though to much more complex effect, in Smart's 'On the Immensity' (1751). This poem in particular behaves as a kind of cartographic tour d'horizon, sweeping like an Ortelian atlas from the planets in the cosmos to 
the depths of the sea, and then assuming the more local and domestic eye of a Saxton (the mapmaker who in 1579 'gave the English people ... the first precise and detailed image of [her] rivers and forests, towns and parkland') to move through forests to plains to pastures. ${ }^{52}$ In Roman courts of law, lawyers invoked the visual through powerful rhetoric to sway verdicts, and the invocation of enargeia - using vivid language to bring a scene before auditors' eyes - could mean the difference between life or death. ${ }^{53}$ Smart's invocation of cartographical tropes, though, directs readers to questions of eternal life. At the start of the poem Smart combines lyrically rapt repetition - 'Thou art there' - with divinely-scaled visions of place:

What tho' th'Almighty's regal throne be rais'd

High o'er yon azure Heav'n's exalted dome

By mortal eye unken'd — where East nor West

Nor South, nor blust'ring North has breath to blow;

Albeit He there with Angels, and with Saints

Hold conference, and to his radiant host

Ev'n face to face stand visibly confest:

Yet know that nor in Presence or in Pow'r

Shines He less perfect here; 'tis Man's dim eye

That makes th' obscurity. ${ }^{54}$

Though 'azure Heav'n's exalted dome' suggests maply territory - we may think of those blue summits of hemispheres in atlases - we have already left it. Mortal eyes, with or without 'th'assisting glass', can't discern properly here, at God's throne above heaven. ${ }^{55}$ Nor can the cherubs of the winds blow, for in this supra-natural place, at each point of the compass there is no breath to puff the cheek and fill the sail. God's glory is no less on earth, but the kinds of 
certainty that maps provide may occlude faith in him. In the 'Song to David', as William E. Levine has shown, Smart reworks a verse from Proverbs:

Vain are the documents of men,

And vain the flourish of the pen

That keeps the fool's conceit. ${ }^{56}$

Smart does not see how 'Man's dim eye' could ever be infallible, telescopes or microscopes notwithstanding. We might note, however, that in his last published writing he seems to have reached some kind of accommodation with the certainty of accurate measurement, for in 'Truth', his tenth hymn 'for the amusement of children', the compass is God's. The two kinds of authentication meet here, to seal firm assurance for very young minds:

The stars, the firmament, the sun,

God's glorious work, God's great design,

All was finish'd as begun,

By rule, by compass, and by line. ${ }^{57}$

Maps work by symbolic representation, and for the pre-modern mind some of the most familiar symbols were religious or political emblems. Infallibility is not possible for humankind, but the earth is teeming with signs and indicators offering emblematic models for improvement. Guest conveys the crowded eagerness of Smart's rush to emblematise, observing how his 'use of analogy' expresses 'the over-abundant complexity which lends a continual sense of urgency to his poetry'. ${ }^{58}$ In the writings of the thirteenth-century Franciscan friar, Saint Bonaventure, Blanford Parker sees useful explication of how the analogical works as a Christian mode of thought. This passage from The Ascent of the Mind to God sets out the ground: 
... [f]or every creature is by nature a sort of picture and likeness of that eternal wisdom, but especially that which in the book of Scripture is elevated by the spirit of prophecy to the prefiguration of spiritual things. ${ }^{59}$

Smart, along with Traherne and Blake, has been identified by Parker as a visionary poet who 'describe[s] elaborate patterns of creaturely illumination': all three illuminate emblematically through observation of plants, creatures and their relationships. In Parker's schema, such attitudes are untimely, late and residual amongst mid eighteenth-century scepticism about older, enthusiastic modes of theological explication and the spiritually elaborate. ${ }^{60}$ After Samuel Butler's devastating satires, the Augustan becomes the era of attention to detail, experience and the quotidian. Now under question is the emblematic mode, the mode 'in which the poet, struck by the epiphanic force of the natural, creates a vision where each detail is suffused with spiritual significance' ${ }^{61}$

Smart worked early and late with brilliantly jewelled, contemplatory emblems, and evidently was interested in the power they could hold: when teaching at Cambridge he had borrowed Andrea Alciati's Book of Emblems - that by then unfashionable sixteenth-century manual of zoological semiosis: its stamp is in his work. ${ }^{62}$ In 1765 , the sixth hymn in his year's cycle of praise calls upon a familial creature to praise God: 'thou of filial love the type, / O stork! that sit'st upon the fir'. ${ }^{63}$ Why filial, not maternal? The commentary for Alciati's thirtieth emblem explains: as the mother stork 'in her airy nest' nurtures her children, she looks forward to the time when they will help her. Her 'devoted offspring' will 'bear the weakened bodies of their parents on their shoulders,/ and offer them food from their very mouths. ${ }^{64}$ Smart had been using such emblems for many years - providence instructs the hen turkey, who then teaches her chicks to feign death in his 'Omniscience' Seatonian poem - but the filial love of Smart's storks must represent the Son's for the Father, and ours for the Trinity. In Alciati the emblem merely illustrates a favour returned, but set in a devotional 
context it stands for the sacramental, eucharistic acknowledgement of Christ's 'matchless deed' ${ }^{65}$ This is Jean Baudrillard's 'first phase' of the image as used in human culture, where it uncomplicatedly represents sacred truths: 'the image is a good appearance: the representation is of the order of sacrament. ${ }^{, 66}$

Before we leave Smart's devotional poetry, and staying with parenthood, we should return for a moment to the suckling mermaid and her 'scaléd' child in the Alphonso Psalter, and to Harriet Guest's discussion of the Seatonian poems: not least her insistence on their dependence on the Psalms as inspiration, and Smart's new placing of the figure of the poet 'as the psalmist capable of expressing the universal integrity of Christian concern. ${ }^{, 67}$ It seems to me that the pictorial elements in Smart's poems embody some of the tensions between 'natural' and 'revealed' religion that Guest explores in her depiction of Smart's position in mid-century Christian debate: the practical, everyday rapprochement between daily observance and commerce that natural religion represents, versus the revelations, miracles and mystery of revealed religion. ${ }^{68}$ Through the figure of David, Smart is restating the importance of the power of God and the inadequacy of man in the face of this - the God whose thoughts are not our thoughts, nor his ways our ways, and who surpasses human understanding: 'be not wise in your own sight. ${ }^{, 69}$ Both Smart's attraction to and scepticism about maps - as opposed to emblems - seem articulated here in his 'Song to David' mermaid, who stands in the Alphonso Psalter as an impossible, spiritual emblem of nurture, generosity and parental love, in opposition to her mirroring, self-absorbed counterpart on maps, where man makes up his own scales.

In the fallen world, Smart knows that both linguistic and pictorial representation are capable of double-speak, and for the second part of this essay we turn to a very secular, even profane, article published in Smart's journal The Midwife (1750-1753): the third, the number for December 1750. Here Smart's cartographical imagination turns to political satire, and the 
capacity of maps faithfully to represent is the object of mockery. Smart is writing under the cloak of his bizarre editorial persona Mary Midnight; she is made to apologise for her oldfashioned analogical disquisition: “'I hope an old woman's fondness for her own conceits will be excused. ${ }^{70}$ Mrs Midnight asks readers to imagine tipping the map of Europe up so that it is vertical, and observe with her how clearly it takes female form:

It is no Wonder that Women are particularly honoured in this Part of the World; ${ }^{71}$ for Europe itself, if we consider her Figure in the Map, will appear to be nothing else but an Old Woman. This will be obvious to any one who turns the North East, or upper Corner of the Right hand of her Map or Picture towards himself: And in the common Position of the Map the same may be discovered; only she then seems as if going to stand upon her Head in the North West Corner of Africa, whereas in the other Way she appears erect Or again, we may suppose her lying on her Back, with her Face turned to the Right, towards the Mediterranean Sea. ${ }^{72}$

Try it: this does actually work. Smart/ Midnight then quickly signals the shifting, unreliable nature of this new map he seems to have invented:

Either of these, I will venture to say, is as likely a Representation as ever was seen in a Christmas Fire, or in the Clouds that adorn the Horizon at the Close of a Summer's Day. ${ }^{73}$

Parallels are then made between nation and female anatomy, from the shining crown of Portugal, down through the head of Spain, the breast of France, the intestines of Holland and Germany, and at last to the dubious dispensation of waters - now under the broad petticoat of Eastern Europe - into the Black Sea. There are ancient literary precedents for 
anthropomorphising maps: Aristophanes' comedy Lysistrata contains a description of geographical areas figured as a woman's body, and Smart, the erstwhile Cambridge don, must have known this. ${ }^{74}$ Shakespeare played bawdily with this conceit in The Comedy of Errors, where Dromio makes a sort of negative blazon of Nell in the kitchen: 'she is spherical, like a globe; I could find out countries in her. ${ }^{75}$ France is her forehead, and England her chin. Shakespeare spares us the Netherlands, which is more than Smart does.

It is not in literature, however, that we should seek for the origin of this analogy, but in geography. For Mrs Midnight is not imagining, but describing. Again, as above - but in a very different context - this cartographical foray is ekphrasis, not fantasy. There exists a whole tradition of printed maps which represent twice over, simultaneously conveying topography and something else: a rose, a lion, or Pegasus. Prominent among these cartographical curiosities is a whole tradition of 'caricature' or 'anthropomorphic' maps in which the maps are also human bodies. ${ }^{76}$ It may have begun with the Ebstorf map of $1290-$ in which the body of Mediterranean Europe is also the body of Christ, and it reached its profane nadir in the run-up to World War 1, when, in propaganda maps, Europe bristled with crude national stereotypical images, each neatly fitted to its own border. ${ }^{77}$

One of the earliest fully realised anthropomorphic maps was a simple, quite schematic but arresting image of Europe figured as a woman, a queen with orb and sceptre, looking exactly as if one had 'turn[ed] the North East Corner of the Right hand of her Map or Picture' towards oneself. Michael Wintle explains that this 1537 image - from an Innsbruck printer who Latinised his name to Bucius - was designed to reflect the glory of the Hapsburg Empire, and to flatter his employer Ferdinand, himself later to become Holy Roman Emperor. '[T]he brilliance of the conceit caught on' and it found a larger audience in Sebastian Münster's version, in the 1544 edition of his Cosmographia. ${ }^{78}$ Most pertinent here, however, 
is a reworking of this image entitled 'Europe in the form of a virgin', from 1581: it appeared in a Czech edition of Heinrich Bunting's Itinerarium Sacrae Scripturae.

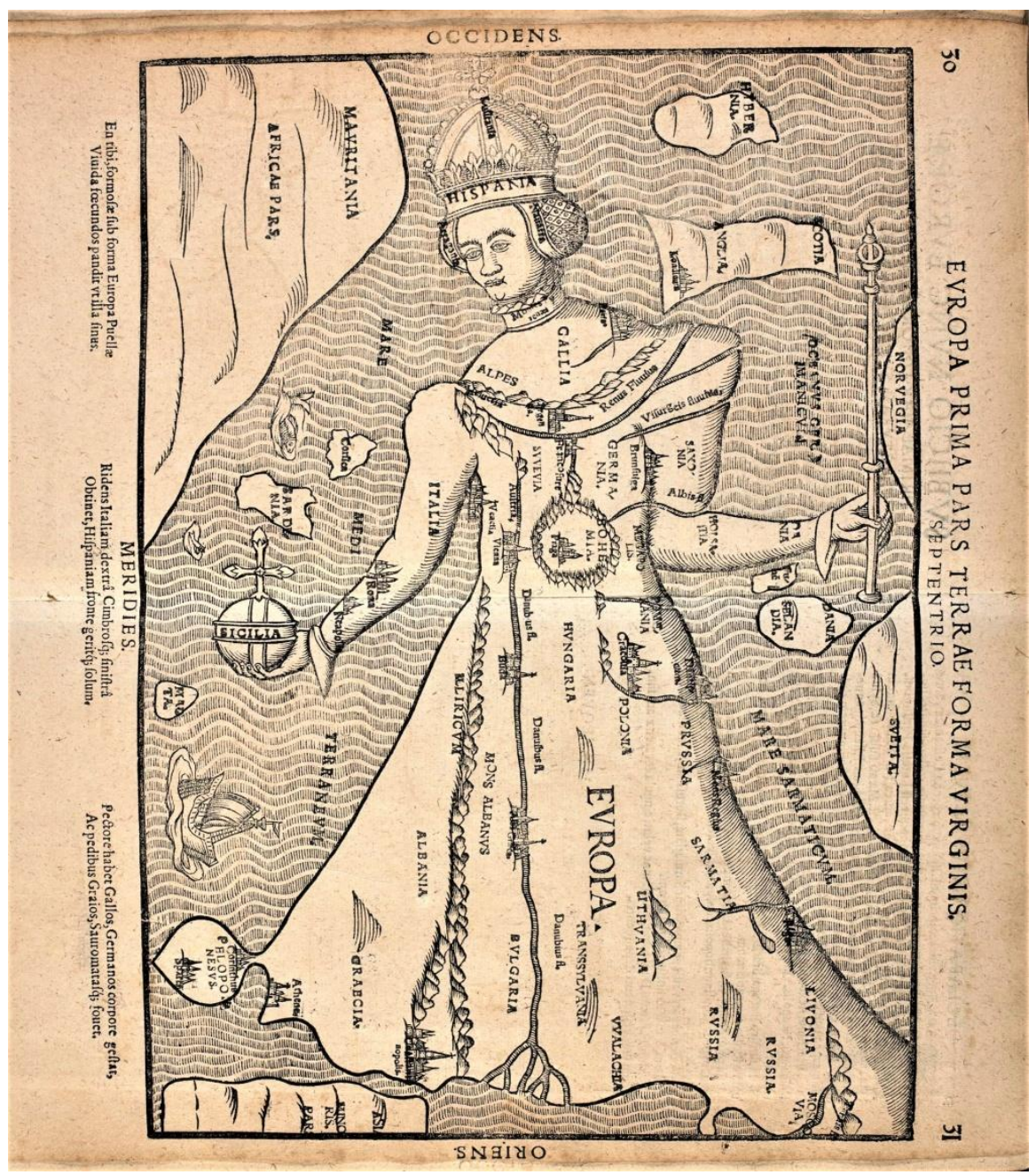

All of these became known as the 'Europa Regina' maps, although care must be taken with gendered readings of Bucius's original image, since Wintle relays a credible suggestion that 'she' represents the Hapsburg Emperor himself. ${ }^{79}$

Smart had at hand, or was remembering, the Bunting map. His piece - characteristic of the Midwife's modus operandi - is a bawdy bit of tomfoolery which does not very well conceal effective and directed satirical sallies. Mrs Midnight's description begins with Portugal and Spain: 'If all Europe be a Woman, this large Peninsula must certainly be her Head.' Portugal is an ornament 'in the Crown of that Head', with the British-held Gibraltar as 
the jewel in the crown. The Pyrenees make a 'beautiful Necklace of Pearls and Diamonds', fitting for 'a lady of such rank in the World as Madam Europa' ${ }^{80} \mathrm{Mrs} \mathrm{M}$ is grudgingly generous to the old enemy France, which is placed below her shoulders, and includes the heart: 'As the Seat of Life is much in this Division, we may fancy some of it shadowed out in the Vivacity of a Frenchman.' But her trademark irony nails that shallow boastfulness so often then ascribed to the Gallic character: 'The Neck and Breast are represented by this Kingdom, which will doubtless be as proud of the Honour I assign to it, as it is of its many other Advantages.'

Mrs M will not allow 'all the noble Parts' to France, but 'would give some of them, how unphilosophical soever it may seem, to my native country of GREAT- BRITAIN.' This is the 'Left Arm in our Anatomical Disposition', which, though it 'appears as cut off from the Body' is 'ever ready to rise to the Assistance of those Parts with which it has no natural Connection. ${ }^{81}$ This description, so strange when the map is merely imagined, confirms it as describing Bunting's 1581 image, where the sceptre has lost the pennant it had in the Bucius/Münster version, and where 'Anglia' and 'Scotia' combined do indeed look like a detached upper arm, floating untethered in the North Sea above the Queen's right shoulder. ${ }^{82}$ There is a link here to Smart the devout poet: a very similar image of a 'cut off' Britain had appeared earlier in 1750, in an astonishingly different context, as part of the first Seatonian poem: that same 'On the Eternity' already remarked for its cartographical bent and volcanic 'Aetna' ${ }^{83}$ Also discernible in the poem, as elsewhere in the Seatonian poems, is the influence of Thomas Burnet's Sacred Theory of the Earth which was equally geographically specific in its catalogue of annihilation. As the earth 'severs to the centre', and rocky continents tumble aflame into the sea, the prophet poet at his most Blakean apostrophises England and laments her demise: 
O Albion, O my Country; Thou must join,

In vain dissever'd from the rest, must join

The terrors of th'inevitable ruin. ${ }^{84}$

Mrs Midnight's profane, patriotic disquisition of later that year seems to retain some imagememory of that detached limb.

The map of Europe as described by Mrs M. is not of a queen, or even an emperor, it is of an 'old Woman.' This is a loaded term used by Smart in the Midwife for a number of sometimes conflicting - reasons, but it would be wrong not to note its levelling and feminocentric potential here. This is not the place to re-pursue all the gender implications of Smart's choice of persona, but in an important early indication of the continuities of his writing life, Fraser Easton found, alongside the strange patterns of exclusion and reinclusion in the Jubilate Agno, a 'maternal matrix' of female power in that sometimes overtly misogynist poem. ${ }^{85}$ I have argued elsewhere that the very fact of the print existence of Mary Midnight's confident, sturdy and forthright voice has a positive effect on some subsequent women writers. ${ }^{86}$ Whilst we should note, in this Midwife number, the presence of a tiresomely typical misogynist poem just before Mrs Midnight takes on the geographers, the conflict of implication here should be seen, I suggest, as part of the attraction and repulsion that the potentialities of gender difference held for Smart, as remarked by Easton in the later poem. ${ }^{87}$ Curiously, women wishing to enter the world of learning may have been assisted practically by Mrs Midnight, for Hester Chapone was perhaps remembering this piece when she recommended curious maps to young women learning at home: 'thus Italy has been called a boot - and Europe compared to a woman sitting. ${ }^{, 88}$

Madam Europa seems to have held a fascination for Smart, and this concept is powerful confirmation of Smart's unified sensibility as a writer, despite the three apparently dissevered versions of the man facing Smart scholars. For not only is she present in Mrs 
Midnight's jesting editorials and the Seatonian Smart of the poetical establishment, but also in the rapt, paratactic spiritual poetry of his asylum years. In his discussion of the Jubilate Agno, Hawes notes its xenophobic aspects: 'Smart's envisaging of England's global role is embedded in expansionist ideologies ${ }^{89}$ This is especially salient in this poem's version of Madam Europa; Smart, Hawes says, "comes up with an international version of the "body politic"'. We now have a better idea of where it 'comes up' from, for here, in the prophecies of the expansionist ' $\mathrm{C}$ ' section, are some familiar cartographical configurations: 'For England is the head of Europe in the spirit', 'Spain, Portugal and France are the heart', 'Holland and Germany are the middle' and 'Italy is one of the legs.'90

In the Midwife's ludic cartography we find that Britain, despite seeming to be cut off, and thus 'released from the mutual Engagements it might otherwise be under with the fellow Members', still retains, as above, a communal link with all of Europe. In the past, 'this amputated Limb' has been 'more assiduous than any other', and as we saw, 'ever ready to rise to the Assistance of those Parts with which it has no natural Connection.' Mrs M naming her creator - suggests that in future it should also move to act against France, in a strange spirit of self-interested chastisement:

[i]f (Great Britain) would now and then strike a sudden and smart Blow on the Breast, recoiling immediately to its own proper Situation, the Skilful in this Science think it would Act more for its own separate Interest.

It is a measure of the complexity of this metaphor that by now we are unsure if 'this Science' is geography, anatomy or politics - perhaps it is rhetoric. Indeed, it seems that the conflicted ambiguity of wanting at once to be and not part of the gigantic, misshapen, porous and leaky 'Madam Europa' is very old: as are scrambled motives behind British continental intervention. We have seen the French getting reprimanded lightly, but Mrs M is not afraid to list the gross physical shortcomings of various hapless countries. The British and the 
Germans are gluttons and drunkards, the Poles 'cannot be brought to obey their King or their own Interest', and the 'wild and savage People' of Eastern Europe 'seem to be under no Direction but that of their unruly Appetites. ${ }^{91}$

The idea of a united Europe has a long and complex history, of course, and the Europa Regina map is part of that: Denys Hay chose the Munster image as the frontispiece for his seminal Europe: the Emergence of an Idea (1957). Neal Ascherson notes the rôle of such images in reinforcing a sense of a coherent group identity among disparate countries; the metaphors used to describe her are crucial for her survival. The Bunting Europa Regina map 'tells us, through this trope of nations as parts of one body, that the thought of European unity and the interdependence or complementarity of Europe's Christian nations had already taken hold. ${ }^{, 92}$ Smart's jokey little eighteenth-century satire, based so clearly on this particular anthropomorphic map, has something new to say in this story. Mrs M's attitude, for example, is part of the story of Protestant nationhood Linda Colley tells in Britons, and foreshadows the kind of mid-century 'emergent nationalist philosophy, anti-French and anti-aristocratic' that Gerald Newman has described in his useful anatomy of British nationalism. ${ }^{93}$

The Midwife piece is also significant in an even wider context than the geopolitical, which returns us to the analogical, devotional Smart of earlier in this essay. I am suggesting here that his attention to this anthropomorphic map may have helped him to perceive with fresh clarity the rhetoric of maps: how each imposing new document that claims a purer authenticity than the last might be deceptive, promising what it cannot perform. There is no reverence in the radical Smart of the Midwife for Enlightenment, or for the venerable fathers of mapmaking and geography. He makes this clear in the joyful peroration of his piece:

But all these Difficulties, and all the new Discoveries that can be made by the Imagination of my Readers, I leave them to settle and enjoy; it being sufficient that I have proved, after Botero, Munster, Mercator, Hondius, Heylin and several other 
Geographical Old Women, that the Map of Europe is neither more nor less than an old Woman's Picture. ${ }^{94}$

Mrs M doesn't buy the rhetoric. If a massive, carefully measured, huge three-dimensional continent can be flattened to fit royal folio and then upended to represent a person, then we are in a world beyond empirical proofs and epistemological certainties, and that is the one that Christopher Smart inhabited, early and late. Indeed, envisaging the continuities of Smart's writing life would entail noting the way in which this Midnightian irreverence for authority agrees with the utopian inclusiveness Hawes sees in the Jubilate Agno, where Smart 'redraws the boundaries of a cosmos now imagined as rejoicing in its diversity. ${ }^{95}$

Smart's article does all the busy work of establishing cultural identity that Klein identifies in early modern maps: they provide 'political, ethnological, strategic, social and linguistic information'; they can be 'instrumentalized either as ideal models in whose image an inadequate reality had to be fashioned, as purposeful interventions in contemporary political debates, or as reminders of the proximity of religious and ethnic difference. ${ }^{96}$ More importantly, though, Smart's little satire knows already that this is the kind of work that modern maps do. The piece implies that all human representation is easy to misread or subvert, as ephemeral as 'the Clouds that adorn the Horizon at the Close of a Summer's Day', and liable to be used instrumentally. Smart was an analogically-minded, belated individual who knew intimately the force of classical rhetoric and its power to persuade, and could see it at work in the new documents of the Enlightenment. In this he seems oddly at one with Friedrich Nietzsche - a linguist who had also taught classical rhetoric in the academy - and that philosopher's observation that the human amassing of knowledge was based on false assumptions: the kinds that made maps seem god-like. Humans liked the call to objectivity: they wanted to 'deny the role of impulses in knowledge', and to 'conceive of reason as a completely free and spontaneous activity. ${ }^{, 97}$ Both see that gluttony, drunkenness and unruly 
appetites should have no place in pure knowledge, but also that they shape it, for it is always only ever humans doing the knowing.

Aspects of Smart's religious verse and his satirical prose show that he at once enjoyed, used and distrusted maps. In his cartographical imaginings he implies that we are forever improving the wrong faculties, for while '[o]ur descriptions are better', we nevertheless, 'do not explain any more than our predecessors' - the 'assisting glass' will only help us see better, not to understand better. ${ }^{98}$ Here, classic humanism in a Christian guise, which acknowledges the fallen nature of the surveyors, adventures along a sceptical trail close to the one that Nietzsche thought he was blazing in the nineteenth century. A man who knew the scriptures as well as Smart did would already be wary of the surveyor's cross-staff, for ' $[w]$ ho can find out the height of heaven, and the breadth of the earth, and the deep, and wisdom? ${ }^{99}$ There is more truth to be found in simple Christian emblems and parables representations which always knew about their own instrumental duplicity - than in any map, Smart might say. Those drawings that flatten the world to claim authenticity are human things, and infinitely malleable, but a young stork will always stand for our gratitude to God.

\section{End-notes}

My thanks to the Review of English Studies editor and two anonymous readers: all three made helpful and constructive suggestions that improved immeasurably an earlier draft of this paper. 
${ }^{1}$ Elephants 'normally represented Africa': Michael Wintle, The Image of Europe:

Visualizing Europe in Cartography and Iconography throughout the Ages (Cambridge, 2009) p. 288.

2 'On the Goodness of the Supreme Being', Poetical Works of Christopher Smart IV, ed. Karina Williamson (Oxford, 1987), p. 306 (11. 38- 43). Smart won the Seatonian prize established to reward the best poem in English written on 'the perfections or attributes of the Supreme Being' - for the first five years after its inception. See a good early account of Smart's Seatonian successes in Edward Ainsworth and Charles E. Noyes, Christopher Smart: a Biographical and Critical Study, (Columbia, 1943) pp. 81-87. Betty Rizzo's identification of Smart's commitment to brevitas ('compact concision') and energia ('vigor of attack') is in 'Christopher Smart's Poetics': Christopher Smart and the Enlightenment (New York, 1999), p. 121.

3 These qualities are best illustrated by the more startling juxtapositions in Jubilate Agno. William E. Levine usefully notes 'Smart's levelling faith, his fusion of the holy with the commonplace' : 'Keeping, Deflating, and Transcending “the Fool's Conceit”: Smart's Satiric Hybridization of Satiric and Devotional Modes in his Translation of the Psalms', in Reading Christopher Smart in the Twenty-First Century, ed. Min Wild and Noel Chevalier (Lewisburg, 2013), p. 120.

4 'Ciceronian rhetoric': see for example Quentin Skinner, Reason and Rhetoric in the Philosophy of Hobbes (Cambridge, 1996), p. 184, and Cicero, De Oratore, II. Ixxxvii. 357358.

${ }^{5}$ Blanford Parker, The Triumph of Augustan Poetics; English Literary Culture from Butler to Johnson (Cambridge, 1998), p. 1. The Smart I present here is generally less favourable to Enlightenment modernity than is suggested by, for example, Clem Hawes in Smart and the Enlightenment, p. 5.

6 'On the Goodness', Poetical Works IV, p. 308 (11. 124-25, 129).

7 For what is still the most convincing study of Smart's attitudes to the new natural philosophy, see Karina Williamson, 'Smart's Principia: Science and Anti-Science in Jubilate Agno', The Review of English Studies, 30:120 (Nov., 1979), pp. 409-422.

8 Poetical Works IV, ed. Williamson, p. xvi. Smart called himself 'the Lord's News-Writer': Jubilate Agno, B327, in The Poetical Works of Christopher Smart Vol. 1, ed. Karina Williamson (Oxford, 1980), p. 63. 
${ }^{9}$ Harriet Guest, A Form of Sound Words: The Religious Poetry of Christopher Smart (Oxford, 1989), p. 115. Clem Hawes, Mania and Literary Style: the Rhetoric of Enthusiasm from the Ranters to Christopher Smart (Cambridge, 1996), p. 206.

${ }^{10}$ God is the architect in 'On the Eternity of the Supreme Being' in Poetical Works IV, ed. Williamson, p. 148 1. 27; 'th'ambition of the comprehensive eye' is from 'On the Immensity of the Supreme Being' in ibid.,, p. 187, 11. 86-87. Also see John Barrell on anxieties in the period over the impossibility of comprehending all of the new knowledges: English Literature in History 1730-1780: An Equal Wide Survey (London, 1983), p. 29. 11 'On the Goodness'. PWIV, pp. 307-308 (11. 86-93). For comprehensive and fascinating details of the iconography of the continents as it was used in eighteenth-century maps, see Wintle, The Image of Europe pp. 282-348.

12 Marcus Walsh's pioneering work continues to assist Smart scholars. An item (150) on loan to Smart in 1745 from the Pembroke College library is merely catalogued as 'Senex's Maps'. Walsh glosses this: 'John Senex published a number of maps, and volumes of maps; Smart could have borrowed The Universal Geographer; or Compleat Atlas (London, 1709-27); or A New General Atlas ... The Maps ... engraven or revised by Mr. Senex (London, 1721)': 'A Cambridge College Library in the Eighteenth Century: Smart's Borrowings at Pembroke', The Library: Transactions of the Bibliographical Society 12, no. 1 (1990), p. 48.

13 See epigraph, n. 25, and ns. 50, 51.

14 'Compiled by Christopher Smart, Oliver Goldsmith and Samuel Johnson; introduction by Samuel Johnson' (NUC). Vol. 1 is dated 1759; vols. 2-17, 1761. Vols. 1-3 bear the imprint "Printed for J. Newbery.

15 For maps as culturally powerful documents, see for example Richard W. Unger, Ships on Maps: Pictures of Power in Renaissance Europe (Basingstoke, 2010), pp. 3-7.

16 'On the Goodness' p. 98. Harriet Guest has noted these descriptions as 'emblematic poetic tableaux', but not their resemblance to cartouches: Form of Sound Words, p. 120.

17 J.B. Harley, 'Deconstructing the Map', Cartographia 26 (1989), 4, quoted in D.K. Smith, The Cartographic Imagination in Early Modern England: Rewriting the World in Marlowe, Spenser, Raleigh and Marvell (Aldershot, 2008), p. 8. Smith is building on the work of Bernard Klein, Harley (and others) who have investigated the impact of the new mapmaking on early modern perceptions of identity and space: see for example Klein's Mapping and the Writing of Space in Early Modern Britain (Basingstoke, 2001), p. 6. 
18 The Cartographic Imagination, p. 8: the 'cartographic imagination' is Smith's own term: see his full introduction pp. 1-13.

19 ibid., p. 11 and 10 [my emphasis].

20 The Map Book, ed. Peter Barber (London, 2005), p. 8.

21 Ibid., p. 6

22 J. B. Harley and David Woodward, 'Preface', in Harley and Woodward (eds.), History of Cartography, Vol. 1: Cartography in Prehistoric, Ancient, and Medieval Europe and the Mediterranean (Chicago, 1987), xvi.

23 de Certeau, Michel, The Practice of Everyday Life, tr. Steven Rendall (Berkeley, 1984) p.121.

24 Also see G.P. Finckh's 1663 version of Philip Apian's 1568 map of Bavaria for surveyor cherubs. The Klein statement is from Mapping and the Writing of Space, p. 20.

25 The Ortelius motto is from Cicero: “quid ei potest videre magnum in rebus humanus'. Wintle identifies this as the first atlas in the Image of Europe, p. 253. The Pembroke college library houses Ortelius's late sixteenth-century Album Amoricum: surely Smart was shown this?

${ }^{26}$ Preface, An Epitome of Ortelius, his Theatre of the World (London, 1601?), p. 1.

${ }^{27}$ Speed uses the building of Solomon's temple as a metaphor in his explanation. John Speed, The Theatre of the Empire of Great Britain (London 1614), sig. B2. Klein merely notes its 'Biblical hyperbole' in this regard, Mapping, p. 81. Klein's summation is in Mapping, p. 106. ${ }^{28}$ The Map Book, ed. Barber, p. 8.

29 In fact it's misleading to use the term 'narrative' for these intersections between literature and cartography, since to convey information, or to signify, is not the same thing as to tell a story - so I have reservations about Klein's third conceptual move in what he calls the 'cartographic transaction.' Mapping and the Writing of Space, pp. 3-5, p. 5.

${ }^{30}$ Denis Cosgrove notices how maps' 'appeal to reverie, their ability to record and stimulate anxiety, their silences and their powers of deception': Mappings, ed. Cosgrove (London, 1999), p. 2.

${ }^{31}$ Smart's Midwife magazine has its 'Dissertation on Dumb Rhetoric', which shows a sophisticated understanding of the semiosis of the body (I: 145-6). The 'speech' of inanimate 
objects is frequently read and rendered into verse or prose: see Min Wild, Christopher Smart and Satire (Aldershot, 2008) pp. 27-28.

32 Smart's distrust of human calculations is registered in, for example, Karina Williamson above, and the discussion in Noel Chevalier 'Breaking the Circle of the Sciences: Newton, Newbery, and Christopher Smart's New Learning' in Reading Christopher Smart, eds. Wild and Chevalier, pp. 125-142. Smart nails political posing and hypocritical bombast in the Midwife: see for example 'Mr Justice Bundle's Address to the Grand Jury' (II: p. 102) and the parody of John Hill's Inspector (III: 83-88).

33 [[My emphasis] Harley again: see n. 23 above. 'The exact duplication of any geographical setting is impossible so maps, like all other forms of communication, purposefully fragment and simplify reality': Unger, Ships on Maps, p. 1.

${ }^{34}$ de Certeau, see n. 23. This eschatological globalising is not unique: see Richard

Blackmore's Creation - but I am arguing that Smart privileges the cartographical in ways we don't see elsewhere.

35 The indulgence is from the 'Immensity of the Supreme Being', PWIV, p. 187, 11. 85-86.

Clem Hawes describes Smart's ceaselessly active gratitude in 'Poised Poesis: Ecstacy in Jubilate Agno', in Reading Christopher Smart, p. 95.

36 Psalm VIII, Poetical Works III, p. 17, 11. 53-54.

37 Marcus Walsh thinks that in writing his Psalm translations, Smart worked 'with only the Prayer Book Psalter, and perhaps the Authorized version, open in front of him': Poetical Works III, p. xviii. For a few examples of these 'long-view' Psalms, see the conclusion of Psalm VIII (PWIII: p. 17); Psalm LXXXIX (PWIII: p. 213-219), and Psalm CXLVI (PWIII: p. 373).

38 Psalm XXIV, PWIII, p. 54.

39 That stable context is D.K. Smith's, from the Cartographic Imagination, p. 11. For these psalm comparisons I am using William Fenner's Cambridge Book of Common Prayer from 1733: npn. in volume but ECCO gives p. 216 of 337.

${ }^{40}$ PWIV, ed. Williamson, 11. 38-42, p. 149.

${ }^{41}$ Hymn and Spiritual Songs, Poetical Works of Christopher Smart Vol. II, ed. Marcus Walsh and Karina Williamson (Oxford, 1983), 11. 93-94, p. 54.

${ }^{42}$ See also Hymn XXIII, 'St Matthew' PWII, pp 76-77, where each gospel is assigned to a point of the compass: Matthew, east; Mark, north; Luke, west and John the Divine south. 
${ }^{43}$ PWIV, p. 186, 11. 56-59.

44 Smart, 'Song to David', in PWII, p. 140, 11. 322-24. Harriet Guest noticed the 'painterly or cartographic image' here: Form of Sound Words, p. 271.

${ }^{45}$ My thanks to John Stephens and Rosemary Baines. The Alphonso Psalter was owned by the Archbishop of Canterbury when Smart was a boy. See

http://www.bl.uk/manuscripts/Viewer.aspx?ref=add_ms_24686_f013r

${ }^{46}$ PWII, p. 140, st. 57, 11. 338-339.

${ }^{47}$ Seutter's map was printed in Augsburg, 1735: Wintle, The Image of Europe, plate 25.

${ }^{48}$ Smart, 'On the Eternity', PWIV, p. 150, 11. 78-84, and see Isaiah 2: 12-14.

${ }^{49}$ Smart, ibid., 1. 87. John Senex’s New General Atlas (1721), p.174.

${ }^{50}$ See for instance Jacob Bauthumley, who sees God in 'every green thing, from the highest Cedar to the Ivey on the Wall' (1650): cited in Hawes, Mania and Literary Style, p. 85, and Milton in Paradise Lost, IV: 138-39.

51 Jubilate Agno, PWI, B1: 20, p. 15. Guest, Form of Sound Words, 136, 137.

${ }^{52}$ D.K. Smith, The Cartographical Imagination, p. 62.

${ }^{53}$ Quintilian described the power of enargeia: 'representations of absent objects are so distinctly represented to the mind that we seem to see them with our eyes and to have them before us. Whoever shall best conceive such images will have the greatest power in moving the feelings': Quintilian, Institutio Oratoria, Bk 6: 2, 30.

${ }^{54}$ Smart, 'On the Immensity', PWIV, p. 185, 11. 17-26.

${ }^{55}$ This concept - of God's ascension above the maply plane - is in the King James version of Psalm 57: 'Be thou exalted, O God, above the heavens': 57: 11. Smart has 'For o'er the heav'n of heav'ns thy love/ Inshrines itself in light/And lofty is thy truth above/ The clouds of highest height': PWIII, p. 134, 11. 40-44.

56 'Answer a fool, according to his folly, lest he be wise in his own conceit': $K J V$, Proverbs 26:5. Levine, 'Keeping, Deflating, and Transcending "the Fool's Conceit", Reading Christopher Smart, p. 105.

57 Smart, 'Truth', no. X, from Hymns for the Amusement of Children, in Poetical Works III, p. 334 .

${ }^{58}$ Guest, Form of Sound Words, p. 118 
59 'The Mendicant's Vision in the Wilderness', St. Bonaventura, The Mind's Road to God, tr. and ed. George Boas (New Jersey, 1953): 2:12. In 'A Song to David', Smart figures David's 'science' as based on the seven pillars of the wisdom of God. David has his own emblems: 'The lion and the bee': PWIV, p. 136, st. 38, 11. 223-228.

${ }^{60}$ Parker, Triumph of Augustan Poetics, p. 189.

${ }^{61}$ ibid, p. 189. Guest had previously stressed Smart's poetic creation of 'landscape[s] of animated analogy': Form of Sound Words, p. 115, and also see $257 \mathrm{ff}$. 'As the seventeenth century became the eighteenth ... biblical typology became less and less an natural habit of thought': Walsh, introduction to the Psalms, PWIII, p. xxviii.

62 Walsh, 'Smart's Borrowings at Pembroke' p. 41.

${ }^{63}$ Hymn VI, 'The Presentation of Christ in the Temple' - just before Lent-- Hymns and Spiritual Songs for the Fasts and Festivals of the Church of England (1765) PWII, p. 42, 11. 49-50.

${ }^{64}$ Andrea Alciati, Emblemata, cum Claudii Minois commentariis, Padua 1621 (NY, 1976) p. 172.

65 'On the Omniscience', PWIV, pp. 206-207, 11. 68-77. The 'matchless deed' is from the 'Song to David', PWII, p. 147, 1. 515.

${ }^{66}$ Jean Baudrillard, 'Simulacra and Simulations', in Selected Writings, ed. Mark Poster (Stanford, 1988), p. 170.

${ }^{67}$ Guest, Form of Sound Words, p. $91 \& 66$.

${ }^{68}$ Ibid., p. 99, 103, 111.

${ }^{69}$ Isaiah 55:8; Proverbs 3.

${ }^{70}$ [Christopher Smart], The Midwife, or, Old Woman's Magazine (London, 1751) p. 40. This 'Midwife's Politicks' piece appears in vol. 1 of the collected edition, pp. 137 -142. It is the third number of the magazine, for December 1750: hence the 'Christmas fire' reference later. ${ }^{71}$ This may be irony, for else here in the magazine Mrs Midnight generally shows sympathy for women as the prey of dissolute men: for example, she calls for legislation on behalf of women to protect them from bigamists (Vol. III., No. IV, p. 224). Periodicals perceived British women as 'freer' than those of Catholic countries: see The Ladies Mercury, where in the proverb England is 'a Paradise for Women. but a Hell for Horses.' (No. IV, 17.3.1693) ${ }^{72}$ Midwife, Vol.1, pp. 137-138.

${ }^{73}$ ibid. p. 138. 
${ }^{74}$ Aristophanes, Lysistrata, ed. and tr. Alan Sommerstein (Warminster, 1990) p.137-139. Smart borrowed Aristophanes at Cambridge: Walsh, 'Smart's Borrowings', p. 45.

${ }^{75}$ William Shakespeare, Comedy of Errors, III.ii. 116-117.

76 Ashley Baynton-Williams, The Curious Map Book (London, 2015): for the rose, see p. 5657, the lion, pp. 36-39 and Pegasus, pp. 24-25.

77 The Ebstorf map is reproduced in The Map Book, ed. Barber, pp. 58-59. For a cluster of pre-WWI anthropomorphic maps, see for instance The Curious Map Book, ed. BayntonWilliams, pp. 192-197.

${ }^{78}$ Wintle, Image of Europe, p. 247-248.

${ }^{79} \mathrm{Ibid}$, p. 248 and see p. 247, n. 54: the hairstyle could certainly be a courtly masculine one of the time. Bernard Klein discusses the Münster map without reference to the 'Europa Regina' concept, as 'a visual affirmation of its own erotic/exotic subtext'. His analysis runs counter to Wintle's later identification of the map as a 'tribute to Habsburg power in Europe' (p. 247), or indeed its possible status as a king rather than a queen: Mapping and the Writing of Space, pp. 36-39.

${ }^{80}$ Midwife, Vol. I, p. 138.

81 Ibid., pp. 138-139, and sounding improbably Blairite.

${ }^{82}$ Wintle reproduces both maps for comparison: Image of Europe, p. 248 and 250 respectively.

${ }^{83}$ Karina Williamson tells us that the Seatonian prize was awarded on the $25^{\text {th }}$ March 1750 , so it is reasonable to assume that 'On the Eternity' was written slightly earlier that winter, the winter of the satire: PWIV, p. 428.

84 'On the Eternity of the Supreme Being', PWIV, p. 150, 11. 91-93. Smart knew well the Spectator and in no. 146 Steele quotes Thomas Burnet's geographically specific Day of Judgement: 'frozen Caucasus, and Taurus, and Imaus, and the Mountains of Asia'. For Smart's admiration of the Spectator, see Wild, Christopher Smart and Satire, p. 85.

85 Fraser Easton, 'Christopher Smart's Cross-Dressing: Mimicry, Depropriation, and Jubilate Agno', Genre 31 (1998), p. 196 and e.g. p. 229.

${ }^{86}$ Wild, Christopher Smart and Satire, p. 95-96. In this I register a friendly disagreement with Fraser Easton, and contend that the Midwife is indeed 'predicated' on a (practical, performance-level) ‘valorization of female speech', ibid. p. 239. 
${ }^{87}$ The poem, the last item in the magazine proper before the 'Mrs Midnight's Politicks' section, is a rote faux-classical squib in which Daphne cuckolds Apollo. For Easton, see ibid. pp. $234 \mathrm{ff}$.

${ }^{88}$ Abigail Williams quotes her Letters on the Improvement of the Mind (2:152) in The Social Life of Books: Reading Together in the Eighteenth-Century Home (New Haven, 2017), 265. ${ }^{89}$ Hawes, Mania and Literary Style, p. 207.

${ }^{90}$ Jubilate Agno, C102-105: PW1, p.. 101-102. In B7 Smart petitions for peace in Europe, amongst 'family bickerings and domestic jars': p. 13. Fraser Easton was, I think, the first to notice this strong link of periodical to poem, 'Christopher Smart's Cross-Dressing', p. 226. ${ }^{91}$ Midwife, Vol. I, pp. 140-141.

${ }^{92}$ Neal Ascherson, 'Memories of Amikejo', London Review of Books, 22.3.'12.

${ }^{93}$ Linda Colley, Britons: Forging the Nation 1707-1837 New Haven, 1992: 5. Gerald Newman, The Rise of English Nationalism : a Cultural History 1740-1830 (London, 1987), p. 73. It almost feels as if Linda Colley's New Statesman article on Brexit is discussing Mrs M’s piece: 'An Island, but not in Isolation', New Statesman, Jun 10-Jun 16, 2016: 35.

94 Midwife, Vol. I, p. 142.

${ }^{95}$ Hawes, Mania and Literary Style, p. 211.

${ }^{96}$ Klein, Mapping and the Writing of Space, p. 11.

${ }^{97}$ Friedrich Nietzsche, The Gay Science, tr. and ed. Walter Kaufmann (NY, 1974), p.170, \#110. This point links interestingly with Harriet Guest's arguments about Smart's attitude to scientific advancement: Form of Sound Words, 231, 238.

${ }^{98}$ Nietzsche, The Gay Science, p. 172 \#112. The 'assisting glass' was where this essay began.

${ }^{99}$ Marcus Walsh describes Smart's formidably comprehensive knowledge of the Bible:

“"Community of Mind": Christopher Smart and the Poetics of Allusion', in Smart and the Enlightenment, ed. Hawes, p. 38. The Old Testament question is from Ecclesiasticus, 1:3. 